\title{
3D FDM Printable Polymer Composites and Polymer Nanocomposites: State of the Art
}

\author{
Akash Ahlawat ${ }^{1}$, Ravinder Kumar Sahdevํㅗ R.K. Guptaㄹ, Deepak Chhabra ${ }^{1}$ \\ ${ }^{1}$ Department of Mechanical Engineering, UIET, MDU, Rohtak 124001, India \\ 2 Department of Mechanical Engineering, Manipal University Jaipur, Jaipur, India
}

(Received 10 January 2021; revised manuscript received 26 March 2021; published online 09 April 2021)

\begin{abstract}
This paper deals with the state of the art of the mechanical, thermal and electrical properties of polymer filament reinforced with nanoparticles and their classification for FDM 3D printing. There can be numerous properties that are needed to be improved, but strength and elongation are considered the most effective ones to enlarge the utility of additive manufacturing. To improve mechanical, electrical, thermal properties of the components fabricated by FDM 3D printing, composites and nanocomposites like carbon nanotubes, graphite nanoplatelets, glass fiber, carbon fiber, multi-walled carbon nanotubes, montmorillonite clay, graphene are used as an additive with a thermoplastic polymer. The popularly known thermoplastics polymers that can be used with nanocomposites are ABS and PLA because of their low melting point. This study attempts to contribute various properties of smart filament with nanocomposites that are used in 3D printing techniques. The advancement of printable polymer nanocomposites is enlarging the $3 \mathrm{D}$ printing filaments envelope, by which fabrication of parts is possible with complexity and multifunctionality.
\end{abstract}

Keywords: 3D printable polymer nanocomposites, FDM, Graphene, Carbon nanotubes, Nanofillers.

DOI: 10.21272/jnep.13(2).02020

PACS numbers: $61.46 . \mathrm{Np}, 81.05 . \mathrm{Qk}$

\section{INTRODUCTION}

Additive manufacturing is a joining process of materials by a series of $2 \mathrm{D}$ layers from digital files [1]. It does not require moulding/pattern and other various tools. This technology initiates the advancement of digital fabrication through engineering that involves computers [2]. Additive manufacturing is known as $3 \mathrm{D}$ printing, is a term that relates to technology for layer addition manufacturing. AM techniques open up new chances of greater productivity, lower cost and improved quality in leading production areas [3]. It differs from subtractive manufacturing like casting, grinding, milling, etc. [4-9]. In this technology, objects are fabricated directly from the digital file and no further machining or finishing process is required [10-13]. 3D printing can build a structure of greater strength and complex shape, so it attracts the attention of industries and finds various applications because it uses a variety of applicable substances like ceramics, thermoplastic polymer, etc. [14]. AM also helps in improving the state economy and contributes to a sustainable development goal that is accountable for manufacturing $[15,16]$. Implementation of feasible rules in production is not an easy task which leads companies to take an unclear decision so it is crucial to acknowledge the long-lasting influence of fabrication technology which is selected and utilized [17, 18].

Deswal et al. analyzed the various process parameters to improve the properties of the parts that are fabricated by thermoplastic filament [19]. Many researchers have verified and optimized the result using algorithm techniques [20-23]. Printable biomaterials are made by biodegradable materials for sustainable 3D printing and find their application in the medical industry [24].

Significant aspects affecting the object performance and various characteristics of fused deposition modeling printed parts are shown in Fig. 1. These are the density, type of material, filament quality, water content etc. of raw material, nozzle temperature, bed temperature etc. of FDM printer, humidity, oxygen content as an environmental factor, infill density, layer thickness etc. are process parameters. The most affecting factors are the properties of raw material because the part which is being fabricated is made up of the same material, hence it possesses the same properties.

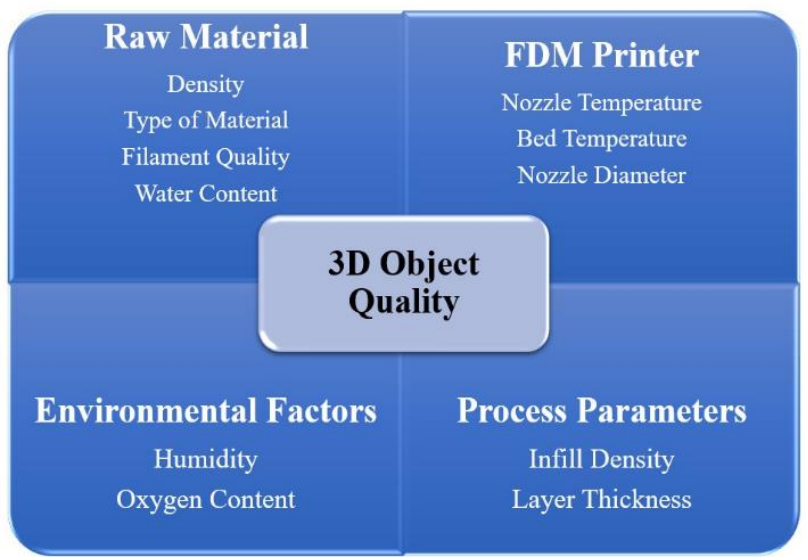

Fig. 1 - Significant aspects affecting the object performance and various characteristics of FDM printed parts

It is noted that specific materials are required for different techniques of additive manufacturing so the material envelopes for AM are somewhat limited. This is the reason that conventional polymer is restricted for high-performance applications. Hence, it became essential to develop a material with improved properties to the extent the potential of $3 \mathrm{D}$ printing. Such high performance can be accomplished by advancing composite filament that is adaptable to the $3 \mathrm{D}$ printing process. The research objectives of present study are:

$\checkmark$ To classify the polymer composite and polymer nanocomposite based on 3D printability.

$\checkmark$ To study the effect of nanoparticles on mechanical properties of $3 \mathrm{D}$ printable polymer composite filament. 


\section{POLYMER COMPOSITE AND POLYMER NANOCOMPOSITE CLASSIFICATIONS ON THE BASIS OF 3D PRINTABILITY}

Composite material is advanced by accumulating long or short fiber to thermoplastic polymers to attain higher mechanical properties. Classification of polymer composites and polymer nanocomposites on the basis of $3 \mathrm{D}$ printability are shown in Fig. 2 . The polymer composite filament is made by combination of two or more constituent substantial with notably distinctive physical or chemical characteristics that, when joined, create a suitable filament possessing valid characteristics that are different from individual material.

Area of such materials widely expanded with the swift advancement of fiber-reinforced polymer composites as they possess marvelous properties like strength to weight ratio, corrosion resistance, lightweight [25]. As they possess great mechanical properties and chemical resistance, so they are widely used in the aerospace and automobile industry. It is noted that chopped composites are simple to develop but continuous composites filaments have greater tensile characteristics [26].

Polymer nanocomposites are those in which nanoscopic particles (inorganic), of size between 10-100 ̊ in at least $1 \mathrm{D}$, are distributed in a polymer matrix (organic) to intensely enhance the functional characteristics of the filament. Nanoscopic particles (inorganic) are nanofillers or functional additives are used as reinforcement in the polymer matrix. Polymer nanocomposites became popular because of the so-called nanoeffect. Even a small amount of nanofillers can improve the properties like thermal, mechanical, electrical, optical or chemical [27].
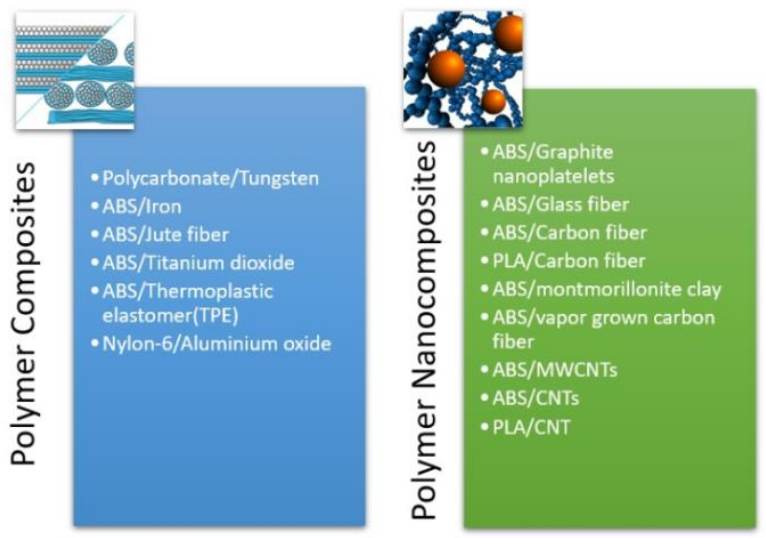

Fig. 2 - Classification of polymer composites and nanocomposites

\subsection{Nanocomposite Materials for FDM Additive Manufacturing}

ABS and PLA are the general thermoplastics for FDM AM having bulk strengths between 35 to $95 \mathrm{MPa}$ and elastic moduli between 1.4 to $3.5 \mathrm{GPa}$. Elastic modulus generally increases and elongation or strain at break is decreased due to the nanoeffect of nanoparticles [28].

\subsubsection{Single-walled and Multi-walled Carbon Nanotube Nanocomposites}

3D printing unlocks the manufacturing of parts that are utilized in the electronic industry in a simplified process with cost-effective and design variation. For accessing such functionality, material evolution is the key ingredient.

Carbon fiber and carbon black as additives enhance the electrical application and structure reinforcement respectively. The advancement of carbon nanotube nanocomposites printable filaments for $3 \mathrm{D}$ printing gains popularity in the electronic industry due to the high electrical conductivity of carbon nanotube [29]. Non-functionalized carbon nanotubes are used to conserve electrical conductivity. Dispersion of the carbon nanotube is essential for the optimum filament performance and printing process so that it may not obstruct the printer nozzle [30].

\subsubsection{Graphene Nanocomposites}

Graphene nanoplatelets consist of small stacks of graphene sheets that can substitute carbon fiber, carbon nanotubes. As it has a $2 \mathrm{D}$ set structure causes greater strength, thermal and electrical characteristics hence such type of nanofillers has been used as multifunctional reinforcement [31].

Graphene improves the conductivity as well as the strength of the component. These components find their application in the electrical industry [32]. Graphene has properties like small resistivity, brilliant thermal conductivity, transparency and greater electron mobility which makes the part more stable. In comparison with graphene-based materials, carbon nanotube nanocomposites have a smooth surface and tensile behavior [33].

\section{EFFECT OF NANOFILLERS ON THE PROPERTIES OF POLYMER COMPOSITES}

The properties of ABS nanocomposite reinforced by inorganic nanofillers: multi-walled CNTs are compared with pure ABS. The filaments are processed by extrusion by twin screws and $1 \mathrm{wt} . \%$ content is fixed for NWCNTs. It is observed that parts that are fabricated with nanoparticles exhibit greater tensile strength, flexural modulus than thermoplastic polymers [28].

ABS with graphene nanocomposite material is produced by a non-solvent process firstly, in an internal mixer and secondly, by twin-screw material extrusion. Tensile strength is computed at 2, 4 and 8 wt. \% of graphene content and optimization was done for graphene concentration by analyzing behavior and tensile strength [34]. As the graphene content increases, Young's modulus increases but ultimate strength (tensile) decreases. Reason for the decrease in ultimate strength is the bond between the polymer with nanocomposites is not that strong.

To balance between rheological and tensile properties, 4 wt. \% graphene was selected for printing [32]. Elastic modulus and ultimate strength values for pure $\mathrm{ABS}$ and $\mathrm{ABS}$ with different loading of graphene nanoplatelets nanocomposites are shown in Fig. 3.

\section{DISCUSSION AND FINDINGS}

The observed effect for nanoparticles as reinforcement is, increases in Young's modulus and a decrease in 


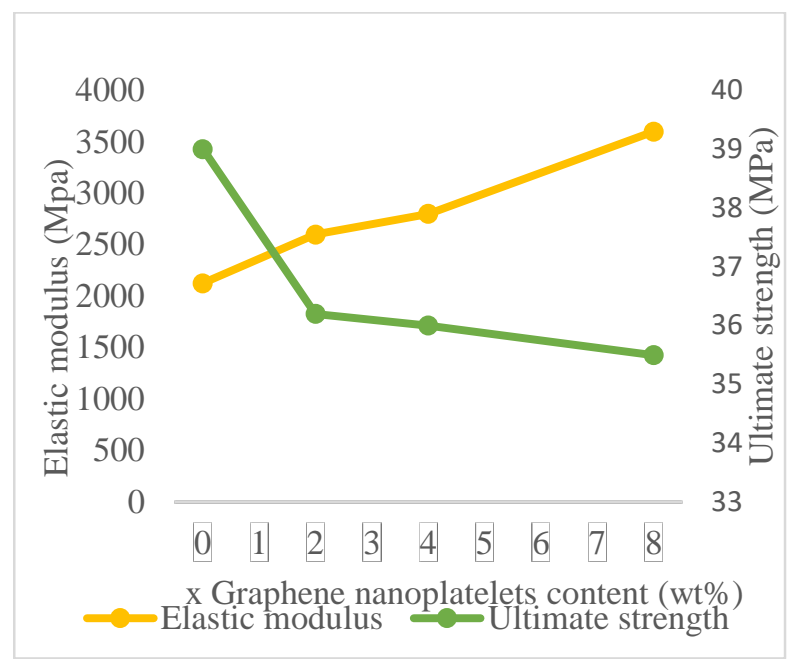

Fig. 3 - Elastic modulus and ultimate strength values for pure ABS and ABS-(wt. \%) graphene nanocomposites

\section{REFERENCES}

1. I. Gibson, A. Mateus, P. Bartolo, Ann. Daaam. 21(1), 1589 (2010).

2. F. Calignano, D. Manfredi, P.E. Biamino, M. Lombardi, E. Atzeni, P. Fino, P. IEEE 105(4), 593 (2017).

3. I. Gibson, W.D. Rosen, B. Stucker, Beam Deposition Processes (Boston: Springer: 2010).

4. M.T. Chen, B. Young, Thin Wall Struct. 136, 267 (2019)

5. M.T. Chen, B. Young, J. Constr. Steel. Res. 151, 174 (2018).

6. M.T. Chen, B. Young, J. Constr. Steel Res. 158, 317 (2019).

7. M.T. Chen, B. Young, Eng. Struct. 185, 400 (2019).

8. M.H. Lai, J.C.M. Ho, Eng. Struct. 125, 124 (2016).

9. M.H. Lai, J.C.M. Ho, Eng. Struct. 67, 123 (2014).

10. K.S. Prakash, T. Nancharaih, V.S. Rao, Mater. Today: Proc. 5(2), 3873 (2018)

11. M. Srinivas, B.S. Babu, Mater. Today: Proc. 4(8), 9049 (2017).

12. J.R.C. Dizon, A.H. Espera Jr, Q. Chen, R.C. Advincula, Add. Manufac. 20, 44 (2018).

13. W.S.W. Harun, M.S.I.N. Kamariah, N. Muhamad, S.A.C. Ghani, F. Ahmad, Z. Mohamed, Powder Technol. 327, 128 (2018).

14. W. Kritzinger, A. Steinwender, S. Lumetzberger, W. Sihn, Procedia Cirp. 72, 1518 (2018).

15. D.R. Eyers, A.T. Potter, Comput. Ind. 92, 208 (2017).

16. S. Ford, M. Despeisse, J. Clean Prod. 137, 1573 (2016).

17. K. Ueda, T. Takenaka, J. Vancza, L. Monostori, Cirp. Ann. 58(2), 681 (2009).

18. R. Sreenivasan, A. Goel, D.L. Bourell, Phys. Procedia 5, 81 (2010).

19. S. Deshwal, D. Chhabra, Int. J. Latest Trends Eng. Technol. 8(4-1), 264 (2017).

20. S. Deswal, R. Narang, D. Chhabra, Int. J. Interact. Des. Manuf. 13(3), 1197 (2019). elongation. The essential direction for polymer nanocomposites to deliver the finest performance is the appropriate distribution of nanoparticles. For the homogeneous distribution of the nanofillers, the twin-screw extrusion method is involved. Material homogeneousness is necessary to regulate the object quality.

The printability is significantly influenced by the nanoparticles as the rheological behavior of the polymer can be affected by nanofillers in a molten state hence loading of nanofillers becomes similarly significant. The reason behind this is the mobility of polymers is constrained by the nanoparticles.

\section{CONCLUSIONS}

Polymer composite and polymer nanocomposite based on 3D printability are broadly classified. The effect of nanoparticles on mechanical properties is that it increases the Young's modulus but slightly decreases the elongation at breaks.

21. D. Yadav, D. Chhabra, R.K. Gupta, A. Phogat, A. Ahlawat, Mater. Today: Proc. 21, 1592 (2020).

22. D. Yadav, D. Chhabra, R.K. Garg, A. Ahlawat, A. Phogat, Mater. Today: Proc. 21, 1583 (2020).

23. S. Deshwal, A. Kumar, D. Chhabra, CIRP J. Manufac. Sci. Technol. 31, 189 (2020).

24. D. Yadv, R.K. Garg, A. Ahlawat, D. Chhabra, Resour. Policy 68, 101767 (2020).

25. L.G. Blok, M.L. Longana, H. Yu, B.K.S. Woods, Add. Manufac. 22, 176 (2018).

26. R. Matsuzaki, M. Ueda, M. Namiki, T.K. Jeong, H Asahara, K. Horiguchi, T. Nakamura, A. Todoroki, Y. Hirano, Sci. Rep. 6, 23058 (2016)

27. A.N. Dickson, K.A. Ross, D.P. Dowling, Compos. Struct. 206, 637 (2018).

28. S. Meng, H. He, Y. Jia, P. Yu, B. Huang, J. Chen, J. Appl. Polym. Sci. 134, 7 (2017)

29. S.W. Kwok, K.H.H. Goh, Z.D. Tan, S.T.M. Tan, W.W. Tjiu, J.Y. Soh, Z.J.G. Ng, Y.Z. Chan, H.K. Hui, K.E.G. Goh, Appl. Mater. Today 9, 167 (2017).

30. J.F. Christ, N. Aliheidari, A. Ameli, P. Potschke, Mater. Des. 131, 394 (2017).

31. S. Dul, L. Fambri, A. Pegoretti, Compos. A. Appl. Sci. Manuf. 85, 181 (2016).

32. D. Zhang, B. Chi, B. Li, Z. Gao, Y. Du, J. Guo, J. Wei, Synth Met. 217, 79 (2016).

33. K. Gnanasekaran, T. Heijmans, S. Van Bennekom, H. Woldhuis, S. Wijnia, G. de With, H. Friedrich, Appl. Mater. Today 9, 21 (2017).

34. A. Dorigato, V. Moretti, S. Dul, S.H. Unterberger, A. Pegoretti, Synth. Met. 226, 7 (2017).

\title{
Полімерні композити та нанокомпозити для FDM 3D друку: сучасний стан
}

\author{
Akash Ahlawat ${ }^{1}$, Ravinder Kumar Sahdevํㅏ, R.K. Guptaㄹ, Deepak Chhabra ${ }^{1}$ \\ 1 Department of Mechanical Engineering, UIET, MDU, Rohtak 124001, India \\ ${ }^{2}$ Department of Mechanical Engineering, Manipal University Jaipur, Jaipur, India
}

\footnotetext{
У статті розглядаеться сучасний стан механічних, теплових та електричних властивостей полімерних волокон, армованих наночастинками, та їх класифікація для FDM 3D друку. Існуе безліч властивостей, які необхідно покрашити, але міцність та подовження вважаються найефективнішими для збільшення корисності адитивного виробництва. Для поліпшення механічних, електричних та теплових
} 
властивостей компонентів, виготовлених методом FDM 3D друку, як добавки використовують композити та нанокомпозити з термопластичним полімером, такі як вуглецеві нанотрубки, графітові нанопластинки, скловолокно, вуглецеве волокно, багатостінні вуглецеві нанотрубки, монтморілонітова глина та графрен. Загальновідомими термопластичними полімерами, які можна використовувати 3 нанокомпозитами, є ABS та PLA завдяки їх низькій температурі плавлення. У цьому дослідженні робиться спроба зробити внесок у різні властивості смарт-волокон з нанокомпозитами, які використовуються в технологіях 3D друку. Розвиток придатних для друку полімерних нанокомпозитів збільшуе оболонку волокон для 3D друку, завдяки чому виготовлення деталей стає складним та багатофункціональним.

Ключові слова: Полімерні нанокомпозити для 3D друку, FDM, Графен, Вуглецеві нанотрубки, Нанонаповнювачі. 